JOHN CONSIDINE

University of Alberta, Edmonton

john.considine@ualberta.ca

\title{
IN PRAISE OF EDWARD PHILLIPS
}

Keywords: English lexicography, plagiarism, dictionary consultants

\begin{abstract}
The aim of this paper is to rescue the reputation of the much-maligned seventeenthcentury English lexicographer Edward Phillips. He has been accused of plagiarizing in his dictionary called New world of English words (1658) from an earlier dictionary, Thomas Blount's Glossographia (1656), and he has been accused of claiming misleadingly that his dictionary was enriched by the contributions of consultants. Both accusations were originally made by Blount. Examining them both - which requires the use of techniques from the history of the book and the social history of science and technology - leads to the conclusion that neither accusation is true, and that Phillips actually made multiple original contributions to the development of the English lexicographical tradition, particularly in the use of consultants and the handling of technological vocabulary.
\end{abstract}

\section{The case against Edward Phillips}

Must this then be suffered? A Gentleman for his divertisement writes a Book, and this Book happens to be acceptable to the World, and sell; a Book-seller, not interessed in the Copy, instantly employs some Mercenary to jumble up another like Book out of this, with some Alterations and Additions, and give it a new Title... Thus it fared with my Glossographia, the fruit of above Twenty years spare hours, first published in 1656. Twelve Moneths had not passed, but there appeared in Print this New World of Words, or General English Dictionary, extracted almost wholly out of mine, and taking in its first Edition even a great part of my Preface; onely some words were added and others altered, to make it pass as the Authors legitimate offspring. (Blount 1673: sig. A2r) 
These words were written by Edward Phillips's contemporary Thomas Blount, very much in dispraise of Phillips himself, and because they have been responsible for giving Phillips the bad reputation against which this paper argues, they call for discussion here.

The Glossographia of 1656 , compiled by Thomas Blount, to which Blount refers in his attack on Phillips, had been the first free-standing monolingual dictionary of English which can be said to have been directed at the general reader. Before Blount's dictionary, three little dictionaries of hard English words had been published - by Robert Cawdrey (1604), John Bullokar (1616), and Henry Cockeram (1623) respectively - but Cawdrey's was primarily a vade mecum to the reading of godly texts such as sermons, and all three smelled of the schoolroom. ${ }^{1}$ Blount had done something new. He had spent, or so he said, "the vacancy of above Twenty years" (Blount 1656: sig. A3r) making a dictionary for gentlemen readers like himself, curious about the technical terms they encountered in their leisure reading of histories or newsbooks, or about "the terms of many Sciences ... as of Logick, Astrology, Geometry, Musick, Architecture, Navigation, \&c. with those of our most ingenious Arts, and Exercises, as Printing, Painting, Jewelling, Riding, Hunting, Hawking, \&c." (Blount 1656: sig. A3v). ${ }^{2}$ The Glossographia was physically bigger than the dictionaries which had preceded it, running to 688 pages against the 332 of Cockeram (1623), and it registered more headwords, 10,577 by one count, as opposed to the 5,836 of the hard-word section of Cockeram (1623) (entry counts from Considine 2012: xxiv-xxv).

Shortly after the Glossographia was published, another dictionary appeared, under the title The new world of English words. Its title page advertised coverage of "All those Terms that relate to the Arts and Sciences", giving a list which extended from theology and philosophy to hunting and fishing. It is dated 1658, Blount's “Twelve Moneths had not passed" being an exaggeration. ${ }^{3}$ As we shall see, although Blount's form of words "extracted almost wholly out of mine" was also an exaggeration, the new

1 For Cawdrey and the godly reader, see Brown (2001); for Cockeram and the schoolroom, see Considine (2010).

2 Although Blount's dictionary was intended for the adult reader, it came to be used by children as well: one extant copy of the second edition (1661) has the inscription "Thomas Hill his Books [sic] 1717" and one of the third (1670) has the inscription "Richard Winckworth Juinir [sic], His Book Anno Domini 1731", both in juvenile hands: they were advertised for sale in Catalogue 146 and List 120 respectively of Rulon-Miller Books, St Paul, Minnesota.

3 A copy of Blount's dictionary now in the British Library (shelfmark E.1573) was bought by the bookseller and collector George Thomason on 23 July 1656, and Thomason tended to buy his books very near the day of publication. Phillips's dictionary very probably appeared more than twelve months after Blount's: it is not registered in the "Supplement of New Books, come forth since August the first 1657. till June the first 1658" in London (1658 sigs. Hhir-Ii1r) (though it is registered in London [166o sig. C2v]), and it is at the end of a list of new releases in a publisher's advertisement in a book which Thomason bought in June 1658 (Herne 1658: sig. V6v, Thomason's being the British Library copy E.1825), suggesting publication in that month, almost two years after the Glossographia. As we shall shortly see, when Blount was writing, the most recent edition of Glossographia had been followed at scarcely twelve months' interval by the most recent edition of Phillips's New world, and this may have coloured his recollection of the interval between the first editions of each. 
dictionary did indeed take many entries from the Glossographia. Its preface was signed by Edward Phillips, who was an emerging minor literary figure: he had contributed liminary poems to a couple of books, translated a couple of romances from the Spanish, and edited a volume of poems by Ben Jonson's friend William Drummond of Hawthornden (ODNB s.n. Phillips; Shawcross 2004: 73-94). A well-informed reader in 1657 might have known that Phillips was the nephew of the controversialist and public servant John Milton, for whom he had done some secretarial work, and a very well-informed reader might have remembered that Milton had published some poetry in the 1640 s, and might even have seen the few sonnets by Milton which had circulated in manuscript since then, but Paradise lost had not yet been begun: nobody saw Phillips as the nephew of a great poet.

Blount himself was a marginal figure in the world of letters. He was a gentleman by birth, and had trained as a lawyer, but because he was a Roman Catholic, he was prohibited from practising as a barrister or solicitor. For the same reason, he had been unable to take a degree at Oxford or Cambridge. For the same reason again, compounded by his father's support for the royalist cause at a time when England was under parliamentary rule, his family estates, from which he might have expected to draw an income, were, in the 1650 s, subject to serious financial penalties. Blount needed some extra money, and sought it by writing. An author writing with the intention of making money from a printed publication would sell a work in manuscript to a bookseller or booksellers, who would then finance its printing and take the profits from the sale of printed copies. This is what Blount did. 1646 saw the publication of his Art of making devises, a translation of a book about emblems, reissued with an enlargement in 1648 and reissued again in 1650, and 1654 saw the publication of his Academie of eloquence, a collection of models for letter-writing, which ran to multiple subsequent editions (Bongaerts 1978: 18-24). Although Blount claimed to have written his dictionary in his spare time, "the vacancy of above Twenty years", he undoubtedly treated it as a commercial property when he sold it to the printer and publisher Thomas Newcombe. ${ }^{4}$ In order to make his next book attractive to a publisher, Blount would have hoped to see the dictionary sell well, and in order to make more money from it after selling it to Newcombe, he would have needed to supply him with additional material for further editions. The appearance

\footnotetext{
The question of who published an early modern English book is sometimes rather intricate (Shaaber [1944] is still a good guide). The answer can often be found by seeing who entered the right to publish it in the registers of the book trade guild called the Company of Stationers (henceforth SR for Stationers' register). The 1646 Art of making devises was entered 26 May 1646 by John Grismond (SR 1: 230), who printed the book together with William Ellis (only identified as W.E. on the title page, but Ellis and Grismond worked together: see SR [1: 101] and McElligott [2007: 133]); it was sold by the booksellers Richard Marriot, Richard Royston, and Humphrey Moseley, and by other booksellers, and the title page exists in four versions, each one for Marriot, Royston, and Moseley, and one not naming a bookseller. The 1654 Academie of eloquence was entered 10 September 1653 by Humphrey Moseley (SR 1: 429), who engaged the printer Thomas Newcombe to print it; the title page therefore reads "printed by T. N. for Humphrey Moseley". The 1656 Glossographia was entered 3 November 1655 and again 27 June 1656, both times by Newcombe (SR 2: 17, 2: 67), and the title page reads "Printed by Tho: Newcomb, and are to be sold by Humphrey Moseley ... and George Sawbridge".
} 
of a rival publication in the form of The new world of English words was therefore a problem for Blount, and when he saw that material from the Glossographia had been incorporated into it, he was understandably vexed.

In fact, Phillips's dictionary did not ruin Blount's sales, although it was an aggressive rival: the Glossographia appeared in a second edition in 1661, followed by a second edition of the New world of English words in 1662, and the Glossographia then appeared in a third edition at the end of 1669 (dated 1670), followed by a third edition of the New world of English words at the end of 1670 (dated 1671). ${ }^{5}$ Meanwhile, Blount had been collecting material for a new law dictionary, Nomo-lexikon, founded on the Interpreter of John Cowell (1607) but with much new material from his own reading (see Bongaerts 1978: 45-7). This appeared at the end of 1670 (TC 1: 58), and was followed at the end of 1671 by a new edition of Cowell, augmented with material from Blount's Nomo-lexikon and published under the title Nomothetes. ${ }^{6}$ Phillips had nothing to do with this competitor with Blount's law dictionary. But it was anger at its publication which led Blount to make the public protest against both the Nomothetes and the New world of words, published at the end of 1672 but dated 1673, which was quoted at the beginning of this paper. ${ }^{7}$

One aspect of The new world of English words which particularly irritated Blount was its claim to have been undertaken with the assistance of a team of consultants. In the first edition, the work is modestly identified on the title page as "Collected and published by E. P."; below this statement, in larger type, is the legend "For the greater honour of those learned gentlemen and artists that have been assistant in the most practical sciences, their names are affixed in the next page." Generously laid out on the following leaf (sigs a2r-v) is a table of 34 names:

Antiquity's, Elias Ashmole, Esq;

Law Terms, Mr. Herne.

Magick, Mr. Turner.

Physick, Dr. Sparks.

Chirurgery and Anatomy, Mr. Ed. Molins. Mr. Will. Molins.

Chimistry, Dr. Currer.

Herbary or Botanicks, Mr. Morgan. Mr. Coles.

Mathematicks, Mr. Moore.

Geometry, Dr. Wybard.

Astrology, Mr. Lilly. Mr. Booker.

Chyromancy, Physiognomy, Mr. Sanders.

Dates can be assigned to the dictionaries of $1669-70$ from their appearance in the trade lists now called the Term Catalogues (henceforth TC): the third edition of Glossographia was advertised 22 November 1669 (TC 1: 24), and the third of the New world was advertised 22 November 1670 (TC 1: 60).

6 TC (1: 90); see Bongaerts (1978: 47-50) and, for the larger context, Johns (1998: 266-323).

7 It was advertised on 21 November 1672 (TC 1: 120). Blount himself (1673: sig. A2r) explained his delayed response to the New world by saying that although it was full of mistakes, "had not those Errors been continued, with new supplies to a Second and third Impression, so little was I concerned at the particular injury, that these Notes (in great part collected from his first Edition) had never reproached his Theft to the World." 


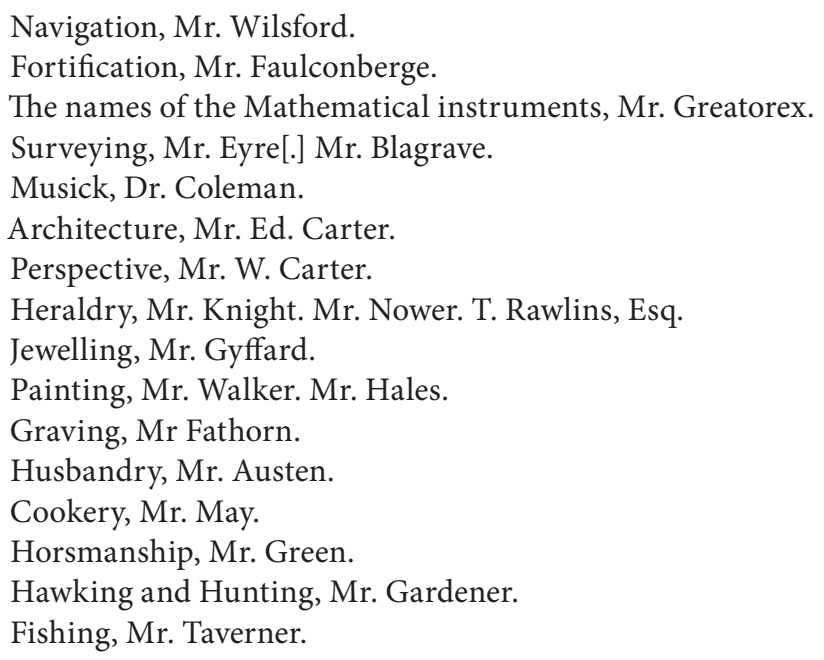

These were Phillips's dictionary consultants. In the "Advertisement to the reader" with which the preliminary matter of The new world of English words closes, the preface to the Glossographia is quoted as saying that a really useful dictionary "would necessarily require an Encyclopedie of knowledge, and the concurrence of many learned Heads" (Phillips 1658: sig. c5v, quoting Blount 1656: sig. A5r). Phillips (1658: sigs. c5v-c6r) announces that "Such an Encyclopedy I present thee Reader with from the Muses, as it was delivered me from the forked top of their Parnassus; for I shall ever acknowledge such peculiar aides as I received from severall Learned Persons." ${ }^{8}$ This attempt to trump the Glossographia rankled with Blount, who wrote that

we find a Catalogue prefixed [to the 1671 edition of the New world of English words] of the names of divers Learned Persons of this Age, Eminent in or contributary to any of those Arts, Sciences, or faculties contained in the following Work. Whereby the Author would at least obscurely insinuate, that those Learned Persons had contributed to or assisted him in it, thereby to advance its reputation; but I believe nothing less, having heard some of the cheif of them utterly disown both the Author and his Work. (Blount 1673: sig. A2r)

So, Blount made two charges, namely that Phillips's dictionary plagiarized his own, and that it boasted of the assistance of imaginary consultants.

History has been on Blount's side. The first serious attempt at a survey of English-language lexicography quoted his complaints at some length, though with the judicious conclusion that he "very much overestimates the injury he had received" (Wheatley 1865: 236). Sir James Murray remarked in his famous lecture on the English

8 He went on to allege that he had also used "the imperfect remaines of a Gentleman who long since begun this Work" (Phillips 1658: sig. c6r), and this must be an invention, as is the description of the New world as "long expected" in a publisher's advertisement (Phillips 1658: sig. Ss4v, item 18): Phillips's dictionary is certainly a response to the Glossographia, not the completion of a work begun "long since". 
lexicographical tradition that Blount considered Phillips's dictionary "with some reason ... to be largely plagiarized" from his own (1900: 32 ). Half a century later, Starnes and Noyes's English dictionary from Cawdrey to Johnson refers to Phillips's "wholesale thefts" (1946: 51) and says "That Phillips' dictionary was extracted largely from Blount's Glossographia, ... that he had a catalogue of the names of eminent persons allegedly contributors to the dictionary - all these are established facts" (1946: 53-4). Robin Alston remarks at the beginning of his Scolar Press facsimile of the New world of English words that "there can be little doubt that Phillips plagiarized Blount's work" and that "it seems likely" that none of the consultants "had any connexion with the dictionary" (Alston 1969 n.p.). The notice of Phillips in the Oxford dictionary of national biography says that "much of" his dictionary "was plundered from the Glossographia." In his chapter on "The early development of the English monolingual dictionary" in the recent Oxford history of English lexicography, Noel Osselton quotes Starnes and Noyes's phrase "wholesale thefts" (2009: 143) and says nothing about the consultants. There is, therefore, a strong tradition of dismissing Edward Phillips as the maker of a plagiarized dictionary, the preliminaries of which were dressed up with the names of imaginary consultants. So why is this paper called "In praise of Edward Phillips"?

\section{Plagiarism and tradition}

A way to examine Blount's claim that Phillips plagiarized from the Glossographia is to look at Blount's use of his own sources. The first of the four parts of his Academie of eloquence is a close adaptation of "Directions for speech and stile", an unpublished rhetorical treatise written half a century previously by the poet and judge John Hoskins (see Bongaerts 1978: 20-4). As for the Glossographia, Blount himself stated in his preface "that I may a little secure the Reader from a just apprehension of my disability for so great an Undertaking, I profess to have done little with my own Pencil, but have extracted the quintessence of Scapula, Minsheu, Cotgrave, Rider" and other lexicographers, including Cowell, "for so much as tended to my purpose; and hope I have taken nothing upon trust, which is not authentick" (Blount 1656: sigs. A5r-v). This was to some extent a modesty topos, with a long ancestry (cf. Considine 2008: 49). However, Blount certainly did draw on the work of other lexicographers, not least Cockeram, as he compiled the Glossographia, as well as doing some highly original work of his own (see Bongaerts 1978: 25-6 and Considine 2012: xxvi). In the preface to his Nomo-lexikon, Blount used very much the same language as he had in 1656: "that I may in some measure prevent the Readers suspition, that my abilities are not commensurate with so great an Undertaking, I'le tell him freely, I have in this Meadow, made little hay with my own fork, but in the more common words have made use of Cowel ..." and other legal lexicographers and commentators, of whom a list follows (Blount 1670: sig. a2r). In fact, about half the entries in the Nomo-lexikon seem to be based on Cowell (Bongaerts 1978: 46). Blount was, therefore, by no means averse to, or ashamed of, using material from other people's books in his own. 
It is difficult to quantify Phillips's indebtedness to Blount, because unless one dictionary entry follows another word for word, it is hard to distinguish adaptation which simply paraphrases or abridges the original, adaptation which has a significant innovative element, and coincidental similarity. Two twentieth-century analyses of different samples show respectively that $49 \%$ and $53 \%$ of Phillips's entries in the New world of English words are taken directly from Blount's Glossographia (Starnes, Noyes 1946: 51; Bongaerts 1978: 28), and Phillips's dependence on Blount in 1658 is by both those measures similar to Blount's dependence on Cowell in 1670. A third analysis shows between $32 \%$ and $41 \%$ of Phillips's entries originating in Blount, nearly all of them with definitions abridged or otherwise altered (McConchie 2013: 112-7), and a fourth shows $38.8 \%$ of Phillips's headwords originating in Blount, often with significant reworking (Miyoshi 2013: 54). So, although there can be no doubt that the Glossographia was the principal source of the New world of English words, none of these figures suggest that Blount's description of it as "extracted almost wholly out of mine ... onely some words were added and others altered, to make it pass as the Authors legitimate off-spring" does its compiler justice. Seventeenth-century English reference books might, indeed, be considerably less original than Phillips's work. For instance, Sylvia Brown and I have shown that well over ninety per cent of the entries in John Dunton's Ladies dictionary of 1694 are copied or reworked from identifiable sources (Brown, Considine 2010, 2013), and recent studies of technical and medical dictionaries of the eighteenth century (e.g. Lonati 2007) show similar patterns of copying and rewording.

Phillips's procedure was legally acceptable as well as being in accordance with contemporary norms. As we have seen, the rights to the Glossographia were sold by Blount to the printer Thomas Newcombe, who protected his right to print the book by having it recorded in the registers of the Company of Stationers (SR 2: 17, 2: 67). ${ }^{9}$ If Newcombe had seen the New world of English words in 1658 as a reprinting of the Glossographia, and hence as an infringement of his rights, he would have proceeded against Nathaniel Brooke, the bookseller who published it, in the court of the Company of Stationers. But he did not: nor did he, Henry Herringman, and John Martin, the publishers of Blount's Nomo-lexicon (entered SR 2: 414), proceed against the publishers of Nomothetes. Outraged as Blount might be by the use in other dictionaries of material which he had compiled, and ready as he was to say that the publisher was "half undone" by it (1673: sig. A2r), the men who actually owned the copyright to that material, and who therefore stood to lose by illegal reprinting, and had a means of redress against it, evidently did not share his outrage. In the case of the New world and the Glossographia, the publishers had good cause to be indifferent: Phillips's dictionary cost twice as much as Blount's, so that they

A dictionary could, earlier in the seventeenth century, have been protected by a royal patent, making it illegal to republish it without the patentee's consent. John Minsheu had obtained a twenty-one-year patent for his polyglot dictionary Ductor in linguas in 1611, and this had protected its publication, for which Minsheu himself arranged financing, in both the edition of 1617 and that of 1625 (see Loewenstein 2002: 141-2). This system would not have applied to Blount, who had sold the right to publish the Glossographia, and it was in abeyance in the 1650 . 
were not competing in the same market. ${ }^{10}$ But even in the case of Nomothetes and the Nomo-lexikon, where the competing dictionary was offered at a price which undercut Blount's, the publishers of the Nomo-lexikon felt that taking some material from the dictionary in which they had an interest was not actionable. ${ }^{11}$

The argument that Phillips's New world plagiarizes Blount's Glossographia depends, then, on Blount's unusual sensitivity to the reuse of his work, and more generally on an anachronistic concept of plagiarism (cf. McConchie 2013: 118). It is more helpful to say that the two dictionaries belonged to the same tradition: Phillips simply took the tradition further than Blount, just as Blount had taken it further than the little hard-word dictionaries of the first half of the seventeenth century. A different dictionary tradition, that of pre-modern China, treats questions of transmission very differently, so that for instance a dictionary whose name translates as Jade chapters, completed in 543, had a successor called Immensely augmented jade chapters, completed 470 years later (Yong, Peng 2008: 192-3). The makers of the Immensely augmented jade chapters stressed tradition in the title of their work, making it invoke what the new dictionary had taken from its predecessor; Phillips stressed innovation, making the title of his dictionary invoke the additions he had made. But that did not make him a plagiarist. Blount's angry accusation has been quoted with approval too often and too uncritically.

\section{Four of Phillips's innovations}

Phillips's use of the hard-word lexicographical tradition is, then, neutral. Let us now turn, as the title of his dictionary invites us to do, from tradition to innovation. Starnes and Noyes (1946: 56-7) point to two of the innovations in the New world of English words. Firstly, Phillips was the first lexicographer of English to begin his dictionary with a history of the English language, in which he gave particular attention to the origin of loanwords (Phillips 1658: sigs. b3v-c4r). Rod McConchie has remarked appreciatively that "there is quite a lot in Phillips's preface which would not be out of place in a twentieth-century textbook on the history of English and English word-formation" (2013: 113 n 11). Second, as Starnes and Noyes put it, the folio format in which Phillips presented the New world "is more attractive and dignified than are those of his predecessors" (1946: 56). Copies of

10 These dictionaries did not have prices printed on their title pages (unlike Dunton 1694, priced on its title page at six shillings), but we know that the third edition of Glossographia was advertised at five shillings in 1669 and the fourth at five shillings and sixpence in 1674 (TC 1: 24, 1: 191; the fifth edition was advertised without quoting a price in 1681, TC 1:433), and the third edition of the New world was advertised at ten shillings in 1670 (TC 1: 60; the fourth edition was advertised without quoting a price in 1678, TC 1: 314-5); a copy of the first edition of the New world was sold for ten shillings in Boston, Massachusetts, in 1666 (Amory 2002: 747). Meanwhile, new editions of the small hard-word dictionaries appealed to the lower end of the market: the 1670 edition of Cockeram's little dictionary and the 1671 edition of Bullokar's were both priced at one shilling and sixpence (TC 1: 62, 1: 75).

${ }_{11}$ The Nomo-lexicon was offered at nine shillings and Nomothetes at eight (TC 1: 58, 1: 90). 
the 1656 Glossographia, an octavo, stand 17 or $18 \mathrm{~cm}$ tall; copies of the New world stand 28 or $29 \mathrm{~cm}$ tall. The larger page size gave Phillips and his publisher space for an engraved frontispiece - "a pompous Frontispiece" according to Blount (1673: sig. A2r) - adorned with images evoking the universities of Oxford and Cambridge, and with portraits of the poets Chaucer and Spenser, the historian William Camden, and the legal antiquaries William Lambarde, John Selden, and Sir Henry Spelman. The New world's innovative folio format presents the reader with more words on a page than could be managed in the Glossographia, and with longer, more readable lines of type. Each column of type on a page of Blount's dictionary is enclosed in box rules, and these are replaced by a single rule between the columns, lightening the visual effect of the page. As Noel Osselton (2009: 142-3) has remarked, these changes go together with an interest in making the dictionary more readable by adding more encyclopedic entries and more proper names.

A third group of innovations shows Phillips making a first move away from the hard-word tradition of his predecessors and towards a wider documentation of the vocabulary of English. He writes in his preface "that there are many words in this book (though fewer than in other books of this kinde) which I would not recommend to any for the purity, or reputation of them" (1658: sig. c2r). The parenthesis is striking, for it shows Phillips's awareness that one of the tasks of the lexicographer is deciding which words to exclude. As for the words which he includes, "knowing that such kinde of words are written, and that the undistinguishing sort of Readers would take it very ill if they were not explained," he explains that "I have set my mark on them" (1658: sig. c2r), and more than a hundred words are duly marked in the dictionary with a typographical dagger, for instance “ $\dagger$ Introruption, (lat.) a breaking in, a rushing in by violence". Sometimes he comments on the words which are thus marked: “ $\uparrow$ Magnality, a greatnesse to be admired at, being a made word, from the Lat. Magnalia, i.e. great and wonderful things". In his overview of the hard-word dictionaries, Osselton calls this feature Phillips's "most striking innovation" (2009: 144), and in an earlier monograph (Osselton 1958), he had shown how previous English dictionaries had hardly ever stigmatized words in this way, and how Phillips' innovation provided a model for lexicographers for a hundred years. Phillips's move was not merely a matter of prescriptivism. Rather, he was trying to make a dictionary which gave a sense of normal English usage. Indeed, introruption and magnality were by no means normal English words: both were registered in the Glossographia, but introruption may have been a coinage of Blount's, and magnality may have been a coinage of Blount's source, Sir Thomas Browne's Pseudodoxia epidemica, the vocabulary of which is very rich and Latinate.

Phillips's stigmatization of abnormal words was, fourthly, of a piece with his rejection of two features of Blount's Glossographia, namely the citation of authors and the provision of etymologies. As for authors, he argued that it was not "proper to quote an Authour for a word that long custome hath sufficiently authoriz'd" (1658: sig. c2r), and that citing authors "as single testimonies for the fantasticalnesse of their own words" was "no lesse needlesse, then abusive and ridiculous" (1658: sig. c5v). 
As for etymologies, it might be argued that, as Kusujiro Miyoshi (2013: 64) has put it, "Blount still saw naturalized foreign words as the primary object of lexicography" while Phillips "was coming to realize that what matters is the systematic treatment of the vocabulary of English, whatever its origin." It was more important to decide whether introruption was a normal English word than to point out that it was derived from a well-formed Latin word. ${ }^{12}$ Phillips's attention to mainstream English usage made his dictionary a suitable starting-point for a tradition of surveying an increasingly broad and general English vocabulary. This tradition would run through the seventeenth-century editions of his dictionary, the last of which had some 17,000 entries, to John Kersey's revision of 1706, which more than doubled the entry count, and on to the even more general English dictionaries of the eighteenth century (see Starnes, Noyes 1946: 84). So it was that Samuel Johnson's first biographer, Sir John Hawkins, concluded that Phillips's New world of English words "must be looked on as the basis of English lexicography" (1787: 173).

\section{A fifth innovation: the use of consultants}

A fifth innovation in the New world of English words was Phillips's claim to have called on consultants in the making of the dictionary. As we have seen, this was dismissed by Thomas Blount, and recent scholars have treated it with scepticism. If Phillips's claim is to be understood at all, a distinction must be made between his list of 1658, reproduced above, which claims that the persons named "contributed their assistance" to the making of the dictionary, and the different list in the edition dated 1671, which as Blount says, does not make that claim directly, but leaves the reader to suppose that the persons named had something to do with the dictionary. The later list need not concern us here: what matters is Phillips's original claim that in 1658 he was assisted by thirty-four consultants. This claim is in fact highly plausible, on several grounds.

The first of these grounds is the nature of the names on the list. Some of them, to be sure, were famous in 1658. Edward and William Molins, the consultants for surgery and anatomy, were both celebrated surgeons, and Edward had been called upon to treat Cromwell himself for a bladder stone in 1656. William Lilly, one of the consultants for astrology, was the leading astrologer of his time; Charles Coleman, the consultant for music, was one of the major English composers of the 1650 . In all, twenty of the thirty-four consultants listed by Phillips are the subjects or joint subjects of entries in the Oxford dictionary of national biography. ${ }^{13}$ But that does not

12 In fact, although introruptio is in early modern Latin dictionaries, it is not attested in classical Latin.

13 They are the following (dates and, unless square-bracketed, descriptions from $O D N B$ ): Elias Ashmole, astrologer and antiquary (1617-92); Ralph Austen, horticulturalist and religious radical (c1612-76); John Booker, astrologer (1602-67); Charles Coleman, musician and composer (d. 1664); William Coles, botanist (1626-62); William Currer, iatrochemical physician (1617-68); William Faithorne, engraver (c1620-1691); Ralph Greatorex, maker of scientific 
mean that all twenty were famous when Phillips used their names. Jonas Moore, the consultant for mathematics, was to earn a knighthood in years to come, but in 1657 he had just returned to London after some years in the fens, surveying drainage works: there were much better-known mathematicians for Phillips to cite, for instance William Oughtred or John Wallis, if he had just wanted names to steal. ${ }^{14}$ Likewise, Elias Ashmole, famous now as the founder of the Ashmolean Museum in Oxford, was a coming man rather than an eminent one: he had recently finished cataloguing the Tradescant collection of rarities, but he was its cataloguer and not yet its owner, and apart from that, his main achievement was editing a collection of English poems on alchemy. If Phillips had been making up names, he could have found a more famous antiquary than Ashmole, for instance William Dugdale. Among consultants who are not the subjects of $O D N B$ entries, some were men of modest distinction: for instance, Edward Carter, the consultant for architecture, had been Surveyor of the King's Works until 1653, but had since then been in eclipse (his brother William, the consultant for "perspective", was much less distinguished), and Humphry Gyffard, the consultant for "jewelling”, was a "Collector of choice rarities" with an administrative position at one of the London prisons. ${ }^{15}$ Some of the consultants are downright obscure, for instance the Mr. Green who advised on horsemanship. Phillips's form "learned Gentlemen and Artists" makes it clear that some of them were not even gentlemen, and hence raises the question again of why he would have named them if they had not actually helped him.

Another reason to suppose that the consultants whom Phillips named really had contributed to the New world is that so many of them can be associated with him. A first kind of association can be seen from the publisher's advertisement at the back of the New world of English words, which lists other books which Nathaniel Brooke had in print or in press in 1657 (Phillips 1658: sigs. Ss1v-Ss4v). One of those which was in print was a translation of a work on the occult by Cornelius Agrippa, done by Robert Turner, the consultant for "Magick" (item 29). Nine further items were by William Lilly the astrologer, who as we have seen was one of Phillips's more celebrated consultants (items 32-40). Another is listed as "The admired Piece of Physiognomy, and Chyromancy" by Richard Saunders, the consultant for "chyromancy and Physiognomy" (item 44). In fact, twelve of Phillips's thirty-four consultants, more than

instruments (c1625-75); John Hayls, portrait painter (d. 1679); John Herne [author of lawbooks] (fl. 1636-166o); William Lilly, astrologer (1602-81); Robert May, cook and author (b. 1588?, d. in or after 1664); Edward Molins, surgeon (1610?-63); William Molins, surgeon and anatomist (1617-91); Jonas Moore, mathematician and patron of astronomy (1617-79); Francis Nowers, heraldic painter (d. 1670); Thomas Rawlins, engraver, medallist, and playwright (c1620-1670); Richard Saunders, medical practitioner and astrologer (1613-75); Robert Turner, writer and translator of occult and medical works (b. 1619/20, d. in or after 1664); Robert Walker, portrait painter $(1595 \times 1610-1658)$.

14 Willmoth (1993: 121) discusses Moore's need to develop a reputation in the late 165os, but remarks of his appearance among Phillips's consultants that "the few mathematical entries in the work are briefer and more feebly expressed than one would have expected if Moore, or others named, had genuinely contributed to it."

15 For the Carter brothers, see Summerson (1975: 134), and for Edward's career (1975: 161-5); for Gyffard, see Grosart (1875: x, xiii-xv) and Bohun (1702: 426-7). 
a third of them, were named in this single advertisement. ${ }^{16}$ Brooke might of course have made books which he had published available to Phillips if the latter were working on the dictionary as an in-house project, but since not all the consultants had published books, this cannot be the whole answer.

One of these twelve was Elias Ashmole: Brooke had published both his collection of alchemical texts and his catalogue of the Tradescant collection (items 45 and 82 in the advertisement in the New world). It may well have been through Brooke that Phillips came to know Ashmole, who would employ him as an amanuensis in the $1660{ }^{17}{ }^{17}$ Ashmole had many contacts among Brooke's stable of authors. One of his closest was William Lilly, to whom he had been introduced by Jonas Moore, another Brooke author, who as we have seen was Phillips's consultant for mathematics; Ralph Greatorex, the consultant for scientific instruments, had known both Moore and Lilly for years. ${ }^{18}$ One of Robert Turner's books has a commendatory note by Lilly, while another is dedicated to the alchemist and antiquary William Backhouse, one of Ashmole's intimates. ${ }^{19}$ Richard Saunders, the consultant for chiromancy, acted as physician to Lilly and dedicated a book to Ashmole, who was godfather to his son Charles. ${ }^{20}$ The other consultant for astrology was John Booker, who was on good terms with Lilly and Ashmole, to whom he dedicated an almanac (Josten 1966: $1.134,160)$. The chemistry consultant, the iatrochemical physician William Currer, was a lifelong friend of Ashmole's (Josten 1966: 1.71). William Coles dedicated his Art of simpling (published by Brooke) to Ashmole in 1655 and William Faithorne engraved Ashmole's portrait in $1656 .{ }^{21}$ Ashmole made an astrological chart for William Molins, which appears in a manuscript of Ashmole's directly after the chart he made for Nathaniel Brooke. ${ }^{22} \mathrm{He}$ was also on friendly terms with a number of members of the Blagrave family, among whom may be the shadowy "Mr. Blagrave" who was one of the consultants on surveying. ${ }^{23}$ It is plausible that Ashmole's name

16 As well as Turner, Lilly, Saunders, and (as we are about to see) Ashmole, the first list in the advertisement identifies printed works by William Coles (items 57-8), John Eyre (item 48), Thomas Rawlins (item 68), Thomas Wilsford (items 49 and 87), John Wybard (item 46), and Phillips himself (items 65 and 88), and the second list identifies works in press by Ashmole (item 20), John Herne (items 23-4), Robert May (item 16), Jonas Moore (item 25), Wilsford (items 1-3), and again Phillips himself (item 18, the New world).

17 Phillips was copying documents for Ashmole's study of the Order of the Garter at a date after 18 January 1663 , and referred knowledgeably to the project in a text with the imprimatur date 16 December 1664 (for both dates, see Hone 1956).

18 For Lilly, Moore, and Ashmole, see Josten (1966: 2.397); for Greatorex and Lilly, see Josten (1966: 2.632 n 3); for Greatorex and Moore, see Willmoth (1993: 47, 123-4 etc.).

19 ODNB, s.n. Turner; for Ashmole and Backhouse, see Josten (1966: 1.76-8 etc.).

20 For Saunders and Lilly, see ODNB, s.n. Saunders; for Saunders and Ashmole, see Josten (1966: $1.105,2.630-1)$.

${ }^{21}$ Josten (1966: 2.672) (Coles) and 1.114 (Faithorne).

22 The charts are in Oxford, Bodleian Library, MS Ashmole 332, fos. 42r (Brooke) and 42V (Molins): see Black (1845: col. 221). Perhaps Molins was Ashmole’s hitherto unidentified "cousin Mullins" (Josten 1966: 2.391).

23 See Josten (1966: 2. 472 n 4) for the family; they were related to the Elizabethan mathematician John Blagrave, and it is possible that if a Blagrave helped Phillips, it was by showing him books or instruments of John's. 
is at the top of the list of consultants because he introduced Phillips to many of the others, perhaps specifically for the purposes of dictionary-making. ${ }^{24}$

If these consultants did actually contribute to the dictionary, they may simply have helped Phillips to improve entries taken over from the Glossographia, but it would have been a laborious matter for him to excerpt entries subject by subject and send them out to consultants. So, they are likelier to have contributed some of the entries which Phillips added to his principal source. Some of the entries which Phillips added do not look like the work of consultants, for instance those for old words taken from the glossary to Speght's edition of Chaucer, and those for classical proper names adapted from an edition of Charles Estienne's Dictionarium poeticum. ${ }^{25}$ But as one reads through the New world and the Glossographia side by side, it becomes evident that there are certain subject fields in which Phillips is making a striking number of additions which could not simply have been harvested from a single source like Speght's glossary. One of these is astronomy, which would have been handled by one of the astrology consultants: the names of a number of stars and constellations appear in English for the first time in the New world, for instance Praesepe and Procyon, as do a number of other terms such as Alphonsin-tables, a set of astronomical tables made under the aegis of Alfonso the Wise of Castile, and as do astrological senses of faces and fall. The latter two are interesting, because they are not the sort of words which would present themselves to a non-specialist as interesting astrological jargon. Another subject-field in which Phillips takes a noticeable interest is surveying, where there appears to be a close link between Phillips's additions and the writings of his consultant John Eyre: for instance, the instrument called a circumferentor is described in very much the terms of Eyre's Exact Surveyor. ${ }^{26}$ Another is painting: the word mahlstick, a stick with a padded top on which an artist rests the hand which holds the paintbrush, is first attested in Phillips, and it is highly plausible that he learned it orally from one of the consultants on painting, which would indeed explain the irregularity of the form in which he gives the word, mosstick. ${ }^{27}$ It is likewise plausible that sand-bag as a support for an etcher's plate came orally from the consultant on "graving". ${ }^{28}$ Another area which

${ }^{24}$ Cf. Josten (1966: 1.120 and 2.730), "It is interesting to note that several of Ashmole's friends and acquaintances are also mentioned in this list."

25 For the Chaucerian words, see Kerling (1979: 87-108); for the classical names, see Starnes, Noyes (1946: 49).

26 With Phillips (1658 s.v.) circumferentor, "it is made of wood, eight inches in length, and four broad, three quarters of an inch thick [etc.]" cf. Eyre (1654: 3), "usually made of wood, containing in leng $[\mathrm{t}] \mathrm{h}$ about eight Inches, and in bredth about foure Inches, and in thicknesse three quarters of an Inch [etc.]." Likewise, Phillips's entry theodolite seems to be related to the description of the theodolite at Eyre (1654: 2-3), and the entry decimal chain seems to be related to the description of that instrument at Eyre (1654: 10).

27 After Phillips (1658), the word occurs in three related texts: Excellency (1668: 93) (as Mol-Stick), Salmon (1673: 122) (as Mol-Stick, in a passage very close to the corresponding one in Excellency (1668), and Holme (1688: 3.145 and 3.369) (both as Mol Stick; the latter passage is very close to those in Excellency [1668] and Salmon [1673]).

28 Phillips (1658) appears to be the first text in which this sense of sandbag is attested, the next being Holme (1688: 3.150). 
may have depended on oral information is that of the names of scientific instruments, for instance bow "a Mathematical instrument to take heights" and declinator "a Mathematical Instrument, to take the declinations of the Planets", both first attested in Phillips in these senses, and the very rare chronodix. ${ }^{29}$ Perhaps it is no coincidence that Phillips's explanation of thermometre (sic) as "a weather-glasse" is echoed by Samuel Pepys's reference five years later to "a very pretty Weather glasse for heat and cold" (Pepys 1663/1974: 84), which he had bought from none other than Ralph Greatorex, Phillips's consultant for the names of scientific instruments.

In some subject areas, Phillips could have used printed sources to make his additions to Blount, for instance the names of plants, particularly those used as medicinal herbs: all-good and all-heal, fenugreec and feverfew, cassia and madder. Like the special uses of faces and sand-bag, these are not particularly outlandish: their inclusion looks like the work of a sensible herbalist or botanist offering a handful of useful plant-names. Another area in which notable additions were made with some help from printed sources is that of the lore of precious stones. Phillips appears to be the first lexicographer to register alabandine, "a kinde of blue, and red stone, provoking to bleed", alectorius "a precious stone of a waterish colour, found in the maw of an old Capon", and the rare carp-stone, "a triangular stone, found in the chap of a Carp, white without, and yellow within". ${ }^{30}$ Some but not all of this lapidary material was from a printed book, an English translation of Wilhelm Scribonius' schoolbook Rerum naturalium doctrina methodica (Scribonius 1621: 28). I have observed other additions in the subject areas of anatomy; architecture; geometry; heraldry; hunting; military affairs; and seamanship. These are all subject-areas in which Phillips claimed to have had the help of consultants. On the whole, the development of these subject areas was a matter of the addition of new entries rather than the revision of old ones, although the entries for at least two architectural terms have been revised for the better, as have those for aloes, cataract, and tunicle.

Some areas show more new material than others: there is, for instance, a fair sprinkling of new heraldic terms, but much less of the vocabulary of painting. This raises the question of the procedures by which Phillips learned from his consultants. In the case of cookery, for instance, some relevant entries have been added or improved, but the changes are not such as to suggest the close involvement of a knowledgeable cook like Robert May, who was named as Phillips's cookery consultant. Indeed, the index of May's The accomplish't cook, published by Brooke two years after the New world, is rich in words such as sparagus, torteletti, tansy, and triffel which are not registered by Phillips (May 166o: sigs. Hh4V-5r). It is still possible that Phillips consulted May, but that he did so briefly and informally. This would be

29 The form chronodix is in Charleton (1654: 78), "Hour-Glasses, or any other Chronodix", from which Phillips's definition "a certain kind of Dial or Instrument, to shew how the time passeth away" could perhaps have been worked out.

30 The form alabandine is quite well attested from the fifteenth century onwards, though it is not registered in dictionaries, and I have not found it associated with Phillips's definition; alectorius and carp-stone are both in Scribonius (1621: 28) (as are rubet, crab's eye, perch stone, all of which were taken over by Phillips), but Scribonius does not have alabandine. 
fully consistent with Blount's report that some of the people named as consultants in the edition of the New world dated 1671 had been heard to "utterly disown both the Author and his Work": on the one hand, some of them were not on the 1658 list, and so Phillips never claimed to have consulted them, and on the other hand, those who were on the 1658 list might have been consulted very casually. If a person asked one a few questions about one's field of expertise, and proceeded on the sole basis of that conversation to identify one as a subject consultant to a dictionary in which that field of expertise was superficially treated, one might indeed disown him and his work.

The hypothesis that Philips offered his list of consultants in good faith can therefore be reconciled with Blount's words as long as we accept that some of them contributed more systematically to the dictionary than others. There is a final point to make about his list of consultants. They contributed information to the New world of English words about the arts and sciences: antiquities and law terms, the occult sciences, physic, surgery, chemistry, botany - and then a long range of applied sciences and useful arts of one sort and another, through architecture down to horsemanship, hawking, hunting, and fishing. All of these contributions ensured that the New world would not have a strong literary bias. In this respect, Phillips was following a path indicated by Blount. The title page of the Glossographia had advertised "the Terms of ... Arts and Sciences Explicated", and the preface had expressed an ambition to emulate the Essay des merveilles de nature et des plus nobles artifices by Etienne Binet, a thematically ordered encyclopedia whose subject matter extended from hunting through the arts and sciences, through the human and natural worlds, to rainbows. ${ }^{31}$ What was a hint in Blount became a principal ambition for Phillips. He was the first English lexicographer to take technology seriously.

\section{Conclusion}

It is no coincidence that Phillips's leading consultant and future employer, Elias Ashmole, was a founding member of the Royal Society, and that other consultants of his were associated with the Society. ${ }^{32}$ Nor is it a coincidence that Phillips would have a long-standing relationship with John Evelyn, another founding member of the Royal Society, who wrote of him that "He is a sober, silent, and most innocent Person, a little Versatile in his Studies, but infinitely Industrious; Understands many Languages, especially the modern; and is master of an English pen (when he will) not inferiour to any I know" (letter of 1667 in Evelyn 2014: 443). ${ }^{33}$

31 Blount (1656: sig. A5r), citing Binet (1621) (as “done by René": it was issued under the pseudonym of René François).

32 For instance Jonas Moore was to become a fellow, and Ralph Greatorex attended meetings of the society.

33 Evelyn was in Evelyn's service by 1663 , as tutor to his son, and was working for him again more than thirty years later, in 1694, as overseer of the printing of Evelyn's Numismata: see Evelyn (2014: 316 n 2, 1024 n 3). 
Dictionaries and natural philosophy went together for many seventeenth-century virtuosi: Descartes, for instance, left a record of a dream he had in 1619, in which he handled a dictionary and a collection of poetry, and "judged that the dictionary meant nothing other than all the sciences gathered together" ${ }^{34}$ Likewise, the "Alphabetical dictionary" which William Lloyd contributed to John Wilkins's Essay towards a real character of 1668 is deeply embedded in the thought of the Royal Society in the 166os (see Lewis 2007: esp. 163-6). It is possible to see Phillips's New world of English words in a similar light, as a document with evident close connections to the experimental and technological work of the years immediately before the incorporation of the society, and to the ethos of collaborative progress in knowledge which would shape the society itself.

Phillips did not just acknowledge the importance of the terminology of the applied arts and sciences in the lexicography of English: he understood that this terminology needed to be gathered by recourse to specialist consultants, and he duly had recourse to consultants, and enriched his dictionary with what he learned from them. This represents a great advance beyond the methodology of his predecessors, for which there is indeed good reason, as the title of this paper proposed, to praise Edward Phillips.

\section{References}

ODNB = Matthew H. et al. (eds.). 2004-. The Oxford dictionary of national biography. Oxford. [online].

$S R=$ Arber E. (ed.). 1913-14. A transcript of the registers of the Worshipful Company of Stationers from 1640-1708 AD. London.

TC = Arber E. (ed.). 1903-06. The term catalogues, 1668-1709 A.D. London.

Alston R. 1969. Prefatory note. - Idem (ed.) facsimile of Phillips 1658. Menston (UK).

Amory H. 2002. British books abroad: The American colonies. - Barnard J. et al. (eds.). The Cambridge history of the book in Britain. [vol. 4: 1557-1695]. Cambridge.

Baillet A. 1691. La vie de Monsieur Des Cartes. Paris.

Binet E. 1621. Essay des merveilles de nature, et des plus nobles artifices. Rouen.

Black W. 1845. A descriptive, analytical, and critical catalogue of the manuscripts bequeathed unto the University of Oxford by Elias Ashmole. Oxford.

Blount T. 1656. Glossographia, or, a dictionary, interpreting all such hard words ... as are now used in our refined English tongue. London.

Blount T. 1670. Nomo-lexikon: A law-dictionary interpreting such difficult and obscure words and terms as are found either in our common or statute, ancient or modern lawes. London.

Blount T. 1673. A world of errors discovered in the New world of words, or general English dictionary, and in Nomothetes, or the interpreter of law words and terms. London.

Bohun W. 1702. Privilegia Londini: or, the laws, customs, and priviledges of the city of London. London.

34 Baillet (1691: 1.83), "Il jugea que le Dictionnaire ne vouloit dire autre chose que toutes les Sciences ramassées ensemble." 
Bongaerts T. 1978. The correspondence of Thomas Blount (1618-1679), recusant antiquary. Amsterdam.

Brown S. 2001. Women and the godly art of rhetoric: Robert Cawdrey's puritan dictionary. Studies in English Literature 1500-1900. 41: 133-48.

Brown S., Considine J. (eds.). 2010. N. H., The ladies dictionary (1694). Farnham (UK).

Brown S., Considine J. 2013. Grub-Street compilers at work: New sources for John Dunton's Ladies Dictionary (1694). - Notes and Queries 60.4: 554-5.

Bullokar J. 1616. An English expositor, teaching the interpretation of the hardest words vsed in our language. London.

Cawdrey T. 1604. A table alphabeticall, conteyning and teaching the true writing and vnderstanding of hard vsuall English words. London.

Charleton W. 1654. Physiologia Epicuro-Gassendo-Charltoniana, or, A fabrick of science natural, upon the hypothesis of atoms founded by Epicurus. London.

Cockeram H. 1623. The English dictionarie, or, An interpreter of hard English words. London.

Considine J. 2008. Dictionaries in early modern Europe: Lexicography and the making of heritage. Cambridge.

Considine J. 2010. Henry Cockeram: The social world of a seventeenth-century lexicographer. Considine J. (ed.). Adventuring in dictionaries: New studies in the history of lexicography. Newcastle (UK): 25-46.

Considine J. 2012. Introduction. - Considine J. (ed.). Ashgate critical essays on early English lexicographers. [vol. 4: The seventeenth century]. Farnham (UK): xv-lxiii.

Dunton J. (ed.). 1694. The ladies dictionary. London.

Evelyn J. 2014 = Chambers D., Galbraith D. (eds.). The letterbooks of John Evelyn. Toronto.

Excellency 1668 = The Excellency of the pen and pencil exemplifying the uses of them in the most exquisite and mysterious arts of drawing [etc.]. 1668. London.

Eyre J. 1654. The exact surveyor. London.

Grosart S. (ed.). 1875. The complete poems and translations in prose of Humfrey Gifford, gentleman (1580). Blackburn (UK).

Hawkins J. 1787. The life of Samuel Johnson LL.D. London.

Herne J. 1658. The modern assurancer. London.

Holme R. 1688. The academy of armory. Chester.

Hone R. 1956. The period of Edward Phillips's work for Elias Ashmole. - Notes and Queries [new ser.] 3.4: 163.

Johns A. 1998. The nature of the book: Print and knowledge in the making. Chicago.

Josten C. (ed.). 1966. Elias Ashmole (1617-1692): His autobiographical and historical notes, his correspondence, and other contemporary sources relating to his life and work. Oxford.

Kerling J. 1979. Chaucer in early English dictionaries: The old-word tradition in English lexicography down to 1721 and Speght's Chaucer glossaries. Leiden.

Lewis R. 2007. Language, mind, and nature: Artificial languages in England from Bacon to Locke. Cambridge.

Loewenstein J. 2002. The author's due: Printing and the prehistory of copyright. Chicago.

Lonati E. 2007. Blancardus' Lexicon medicum in Harris's Lexicon technicum: A lexicographic and lexicological study. - Considine J., Iamartino G. (eds.). Words and dictionaries from the British Isles in historical perspective. Newcastle (UK): 91-108.

London W. 1658. A catalogue of the most vendible books in England, orderly and alphabetically digested. London.

London W. 1660. A catalogue of new books, by way of supplement to the former, being such as have been printed from that time, till Easter-Term, 1660. London.

May R. 1660. The accomplish't cook. London. 
McConchie R. 2013. “The most discriminating plagiarist”: The unkindest cut (and paste) of all. - McConchie R. et al. (eds.). Selected Proceedings of the 2012 Symposium on New Approaches in English Historical Lexis (HEL-LEX 3). Somerville (Mass.): 107-19.

McElligott J. 2007. Royalism, print, and censorship in revolutionary England. Woodbridge (UK).

Miyoshi K. 2013. The first systematic treatment of English vocabulary: Philips's New world of English words (1658). - Karpova O., Kartashkova F. (eds.). Multi-disciplinary lexicography: Traditions and challenges of the XXIst century. Newcastle (UK): 53-66.

Murray J. 1900. The Romanes Lecture 1900: The evolution of English lexicography. Oxford.

Osselton N. 1958. Branded words in English dictionaries before Johnson. Groningen.

Osselton N. 2009. The early development of the English monolingual dictionary (seventeenth and early eighteenth centuries). - Cowie A. (ed.). The Oxford history of English lexicography. Oxford: 131-54.

Pepys S. 1663/1974. The diary of Samuel Pepys. [vol. 4: 1663]. - Latham R., Matthews W. (eds.). Berkeley (CA).

Phillips E. 1658. The new world of English words, or, A general dictionary. London.

Salmon W. 1673. Polygraphice, or, the arts of drawing, engraving, etching, limning, painting, washing, varnishing, gilding, colouring, dying, beautifying, and perfuming in four books. London.

Scribonius W. 1621. Naturall philosophy, or, a description of the world. London.

Shaaber M. 1944. The meaning of the imprint in early printed books. - The Library [ $4^{\text {th }}$ ser.] 24.3-4: 120-41.

Shawcross J. 2004. The arms of the family: The significance of John Milton's relatives and associates. Lexington (KY).

Starnes D., Noyes G. 1946. The English dictionary from Cawdrey to Johnson. Chapel Hill (NC). Summerson J. 1975. The works from 1547 to 1660. - Colvin H. et al. (eds.). The history of the King's works. [vol. 3: 1485-1660 (part 1)]. London.

Wheatley H. 1865. Chronological notices of the dictionaries of the English language. - Transactions of the Philological Society for 1865: 218-93.

Willmoth F. 1993. Sir Jonas Moore: Practical mathematics and Restoration science. Woodbridge (UK).

Yong H., Peng J. 2008. Chinese lexicography: A history from 1046 BC to AD 1911. Oxford. 